\author{
Maciej Kalaska \\ ORCID 0000-0002-9800-3247 \\ University of Warsaw \\ Faculty of Geography and Regional Studies \\ Department of World Regional Geography \\ m.kalaska@uw.edu.pl
}

\title{
THE POSSIBILITIES OF USING THE GUIDEBOOK ANALYSIS METHOD IN RESEARCH ON THE EVOLUTION OF URBAN TOURISM SPACE IN MAGHREB COUNTRIES
}

\begin{abstract}
Research on the evolution of tourism space in Maghreb cities is hindered due to the limited availability and questionable credibility of the data. The guidebook analysis method was developed by S. LISZEWSKI (1999) and it offers a way of analysing tourism space. The main objective of this research paper is to indicate the advantages and disadvantages of using this method to analyse changes in the urban tourism space of the Maghreb. This paper presents conclusions of the research conducted in six locations in the period 2012-2014.
\end{abstract}

Keywords: urban tourism space, guidebook analysis method, tourism space, Maghreb.

\section{INTRODUCTION}

Discussion on the topic of tourism space terminology has been active in the Polish academic community since the 1970s. One of the most recent definitions comes from A. KOWALCZYK (2015, p. 22): tourism space is an objectively existing part of geographical space and simultaneously a part of social space as broadly understood (comprising cultural, economic and political subspaces) which, due to its assets, is (subjectively) perceived by tourists and potential tourists as attractive and is used for tourism purposes, leading to changes in natural and socio-economic environments.

The academic centre in Łódź has been especially interested in studying the evolution of tourism space in cities. The collective analysis of the results of this research carried out using the guidebook analysis method was published by S. LISZEWSKI (2014). S. LISZEWSKI expressed a hope that his summary would revive methodological discussion on the subject of tourism space. The article, therefore, continues the debate on whether it is possible to apply tourist guidebooks in studies on urban tourism.

The author of this article is interested in the urban tourism spaces in the Maghreb countries. The first research papers on the tourism space in this region had already been published in the 1930s (WITES 2015) but research in North African countries is often conducted in a different way than in Poland. It is worth checking whether the guidebook analysis method developed by S. Liszewski is helpful in analysing the evolution of urban tourism space in the Maghreb. The main objective of this paper is, therefore, to indicate the pros and cons of applying the guidebook analysis method for tourism research in that part of the world.

Two cities from each country - considered by researchers as vital for the Maghreb - were selected for analysis: Algiers and Constantine in Algeria; Marrakesh and Tangier in Morocco; and Sousse and Tunis in Tunisia. Each of these locations is characterised by high tourism attractiveness. They are historical cities ${ }^{1}$, therefore, it is possible to develop cultural tourism there. Moreover, four cities (Algiers, Sousse, Tangier and Tunis) are located by a sea or ocean and they offer sandy beaches. Marrakesh and Constantine, on the other hand, are located near or in an area of picturesque mountains: the High Atlas and the Tell Atlas, respectively.

\section{TYPES OF TOURISM SPACE AND THE GUIDEBOOK ANALYSIS METHOD}

S. Liszewski was a Polish researcher for whom the concept of tourism space was especially important (KOWALCZYK \& DEREK 2010). On the basis of the 
nature of tourism activities and the impact it has on geographical space, S. Liszewski distinguished five types of tourism space: exploration, penetration, assimilation, colonization and urbanization (LISZEWSKI 1995). He also confirmed they are present in cities and created a graphical representation of the evolution of tourism space using the example of Łódź (LISZEWSKI 1999).

S. Liszewski's concept was used primarily in research on Poland. In reference to those five types of tourism space, a cycle of tourism space development was formulated (WŁODARCZYK 2009) and a model of the geographical transformation of tourism space was developed (KOWALCZYK 2011). The tourism space of a tropical country was also developed using the example of Brunei. Later on, this approach was used in research on the transformation of the tourism space of Marrakesh and other cities located in the Maghreb (KAŁASKA 2015a, 2015b, 2017).

S. LISZEWSKI (1999), referring to the work of A. ŻEBROWSKA (1996), developed a method of analysing tourist guidebooks. The guidebook analysis method is based on the assumptions that new urban elements regarded as tourist attractions are entered in subsequent editions of guidebooks. They then become part of tourism space. Therefore, the guidebook analysis method essentially makes it possible to study the evolution of urban tourism space on three levels: quantitative, qualitative and spatial. It can be concluded that this method is the most effective in researching urban tourism space (LISZEWSKI 2014, p. 37).

The guidebook analysis method was used in many master's theses (KARASEK 2013, MROZIŃSKA 2006, SZCZEPANIAK 2004). When analysing guidebooks, it is possible to obtain information on tourist attractions, which are the main reason for tourists to visit a city. In the opinion of A. KOWALCZYK (2011), guidebooks make it possible to identify tourism space. They also are a component of tourism space exploration and penetration.

\section{DIFFICULTIES IN STUDYING THE EVOLUTION OF URBAN TOURISM SPACE IN THE MAGHREB COUNTRIES}

According to A. BERTHONNET (2006), sources on urban tourism in this region are numerous and diverse. These include both handicrafts and printed texts (including statistical yearbooks and diploma works), as well as iconographies and audio-visual materials. There are also tourist guidebooks, mainly in French. Despite the diversity, these materials were scattered across various institutions and for the most part have not yet been digitized. It required the author to invest a great deal of time in obtaining the materials.

Sources on the six analysed cities were collected in many different ways. Some of them were purchased in Poland or from Poland via the Internet. Other materials were obtained during research carried out in Polish institutions and from online French book libraries. Many materials were collected during field trips to Paris and to the analysed cities of the Maghreb. They involved searching for relevant literature in ministries, universities and libraries. Despite having access to a variety of sources, the data obtained rarely came in the form of figures. It was difficult, not to say impossible, to analyse the evolution of tourism space on their basis, especially using a sample of six cities.

In long-term retrospective studies on tourism - based on statistical data - it is not possible to distinguish tourism space in the Maghreb cities. Reasons for this, for example, include the inability to accurately reconstruct tourist volume, which is a necessary condition for this space to be present (WŁODARCZYK 2009). Based on research in Poland and abroad, it was found that the first data on the number of tourists staying in the cities of the region was published in the late 1870s, together with the first mention of the numbers of British people staying in Algiers (JORDI 2009). However, the official data from colonial times was too selective to be useful in identifying the transformation of tourism space. This concerned not only statistics from the period of foreign domination in the region, but also from post-colonial times. The credibility of statistics published by the independent Maghreb states raised doubts because of the authoritarian way the countries were governed (after KIREGYERA 2015). The availability of credible source materials on urban tourism did not depend only on the factors indicated by S. LISZEWSKI (2014) such as size of city, number and mobility of tourists, but also on the type of political system. Therefore, the long-term transformation process of the tourism space of the cities of the Maghreb should be assessed on the basis of other than statistical data.

It is often tourists themselves, using the Internet on their mobile phones while they travel, who give origin to a rich body of data about their own spatial behaviours. This way, the constant monitoring of tourism mentioned by S. LISZEWSKI (2014), so difficult to implement especially in big cities of developing countries, is no longer necessary. Thanks to the mobile Internet, databases on tourism space are created in a relatively short time. The information is made available to researchers by the owners of web portals and are subject to statistical and spatial analysis. The work of specialists in the field of big data, results in for instance heat maps depicting the distribution of tourists in a city (LI, XIAO, YE, XU \& LAW 2016). 
In effect, a delimitation of tourism space has been carried out. Data based on geotags, however, is used only in short-term studies on tourism space, but also in relation to Maghreb cities. This is related to the fact that the majority of currently popular websites - and social media - were created after 2004.

Field research was the main method of collecting data on the Maghreb's urban tourism. Researchers collected data mainly based on observations of tourist behaviour, surveys/interviews with tourists (MAJDOUB 2011) and less frequently by taking stock of tourism facilities. However, the data concerned the state of tourism space in the region's cities rather than its development. There were not enough research papers of this type published to be of any help in analysing the changes in the urban tourism space of the region over a longer period of time.

Often, research on urban tourism in the Maghreb involved combining field and small-scale methods of collecting data. The data were derived from an analysis of field survey questionnaires as well as city plans, tourist maps, postcards and films (LEROUX 2008, TRABELSI 2011, WIDMER-MÜNCH 1990). The author of this article believes that the multitude of methods that were applied made it difficult to compare tourist cities. Making general conclusions about tourism space - including many cities in the region with similar characteristics, and not just individual centres - was virtually impossible.

\section{THE POSSIBILITY OF USING THE GUIDEBOOK ANALYSIS METHOD IN RESEARCH ON URBAN TOURISM-SPACE EVOLUTION IN SELECTED MAGHREB COUNTRIES}

The possibilities for studying the process of tourism space development in Maghreb cities are limited mainly due to the lack of source materials or their dubious credibility. Therefore, the author used an indirect method of collecting and analysing data, i.e. the guidebook analysis method.

\subsection{THE CHOICE OF TOURIST GUIDEBOOKS FOR ANALYSIS}

S. LISZEWSKI (2014) stated that it is not always possible to use tourist guidebooks in research on urban tourism space. Therefore, it is important to evaluate them in terms of their suitability for study and, on this basis, select them properly.

Guidebook derived material should meet five criteria (LISZEWSKI 2014). The guidebooks collected for the purpose of analysing the selected cities of the Maghreb undoubtedly met four of the criteria. Above all, the vast majority were published by experts. Authors publishing during the colonial period based their findings especially on long-term expeditions. They were mostly academics (including geographers), artists and travellers (BERTHONNET 2006). Secondly, they included the entire city area in their work, not just some districts. Thirdly, these guidebooks were regularly updated. In support of this statement, one can bring up the fact that the Almoravid Kouba - found in Marrakesh in 1948 by archaeologists under one of the buildings of a religious complex - was mentioned in a guidebook just six years after its discovery (RICARD 1954). Criterion number four - considered the most important by the author - the majority of the collected guidebooks describing the Maghreb were published over several decades by one publishing house. It was the Hachette company, which has been publishing series of guides from 1862 until today - initially it was the Guide Joanne collection, then Guide Bleu. The colonial period was covered by frequent editions in particular, the numerous military actions pacifying the rebellious areas of the Maghreb had stopped and it was finally possible to develop tourism there. This required updating promotional materials, especially guidebooks (BOUTBOUQALT 2009). In the post-colonial period, they were issued a little less frequently, but consistently. This 150 -year period of publication - just as the 100-year period for cities in Poland (LISZEWSKI 2014) - seems to be optimal for studying the evolution of the tourism space of the Maghreb cities. To a large extent, it guarantees the continuity of the analysis practically from the moment when the first fragments of tourism space appeared in the urban centres of this region. The use of a single publishing house made it possible to create a database drawing on one type of source material.

The last condition that should be met by those guidebooks concerns the purpose of publication. According to S. LISZEWSKI (2014), they cannot be made on someone's request. Therefore, promotional or commercial guidebooks should be put aside. In the opinion of the author, the collected guidebook-derived material concerning the cities of Maghreb to a large extent does not meet this criterion, especially when it comes to guidebooks published in the colonial period. R. BARTHES (1957) "exposed" the ideology of Guide Bleu guidebooks and accused them of being dictated by political considerations. The fact that the first guidebook about Morocco had a preface written by General L.H.G. Lyautey - who was not only the General Resident in the French Moroccan protectorate, but also the creator of the region's tourism policy - seems to speak for itself. Tourism guidebooks from the French period can be considered as a material for 
colonial tourist propaganda (BOUTBOUQALT 2009). In the post-colonial era, the narrative of the French authors of the Maghreb guidebooks, as the narrative of press releases (KALASKA \& WITES 2015), was also ideological (neo-colonial). This trend decreased over time. The author, however, did not abandon using the collected guidebooks. At the same time, though, he pointed out that the interpretation of the results of analyses should take into account the beliefs of their authors about the area described and the people living there. It is therefore a limiting factor but it does not disqualify the guidebooks as sources of material for research on the tourism space of the Maghreb urban centres.

Recognizing that the characteristics of the guidebooks collected make it possible to carry out research at a later stage of the procedure a choice had to be made as to which of them should be subjected to analysis. If there were time gaps between Hachette publications (of at least 10 years), other publications in French were selected. If there were no publications in French, English guidebooks were selected. Finally, the evolution of tourism space in the chosen cities was analysed based on 70 guidebooks issued from 1862 to 2014 and devoted entirely to one or two Maghreb countries. 50 of them were published in French. The rest were published in English. 30 of them concerned the colonial period (1862-1955), and 40 from the times of independence (1969-2014). At the beginning of the functioning of sovereign states in the region, tourism guides were not published, hence the gap between 1955 and 1969.

\subsection{METHODS OF ANALYSING TOURIST GUIDES}

After selecting guidebooks for the Maghreb cities, the focus was on their analysis. In total, there were 8207 urban features in the database. At least once they appeared as part of the tourism space of one of the six urban centres and were located inside the area of their administrative borders of 2014.

Due to limits on this article, the author has only presented selected aspects of the analysis, referring to the research potential offered by each of the three data categories, and focusing in particular on quantitative approach.

\section{Quantitative approach}

In quantitative terms, urban tourism space in the Maghreb was examined - as in Poland (LISZEWSKI 2014) - by counting the elements forming it mentioned in the guidebooks. This made it possible to identify the directions and trends of changes in this space. It concerned, in particular, tourism penetration from urban features visited by tourists for sight-seeing and education. Each of them was grouped according to the type of cultural heritage component characteristic for this region. Following S. LISZEWSKI (2014), it was assumed that the grouping is subjective and depends on the size of the city, its history, the activities of local authorities and other factors. Then, the number of urban features in each of the groups distinguished was shown on a timeline. On this basis, how the tourism attractiveness of the examined cities had changed was determined.

In this article, a somewhat broader reference is made to other types of tourism space, which according to S. LISZEWSKI (1999) can also be studied using guidebooks. However, this has not been done so far. By analysing six African cities, changes to tourism assimilation space were also analysed. They consisted of urban features where there was interaction between tourists and residents. In simplified terms, it was assumed that they represented a majority of tourism development elements, placed in guidebooks in the form of a list. This list was located just before or after the basic description of the city or at the end of the book in alphabetically. The exception was accommodation facilities which were considered to be part of tourism colonization space. Studying the example of Sousse, it was found that their number - determined on the basis of guidebooks - coincided with data obtained from other sources only until the end of the 1980s. The guidebook analysis method is not useful for reconstructing the tourist development of the Maghreb cities in 1990-2014. There was a farreaching selection of attractions included in the guidebooks in this period.

The research focused not only on changes in the number of elements forming the tourism space of the Maghreb cities, but also the basic statistical characteristics of this space were determined and interpreted. Among other things, the number of urban features forming the space, which represent a certain variant of a given form (e.g. relative frequency), was calculated in decimal values. By applying the classification of tourism space into functional types (LISZEWSKI 1999), three such variants were distinguished: the space of tourist exploration and penetration treated together, the space of tourist colonization and the space of tourist assimilation. It was a matter of discussion if merging penetration and exploration spaces as one type was legitimate. This was due to the limitations associated with the characteristics of the guidebooks analysed, the design of which forced the identification of these types. Generally, it was a continuous text, in which not only tourism attractions, but also tourism resources that could become attractions were described. This was especially true for the colonial period when the guides were an important instrument of promotion. Therefore, it was impossible to dis- 
tinguish which urban features were part of the space of penetration and which of the space of exploration. In order for the analysis to cover the chosen time range, it was decided to simplify the procedure and merge these forms - the spaces of exploration and penetration - into one type, in accordance with their location in the guide. The urban features described in the guidebooks as a part of urbanization space have been deliberately ignored. This space rarely occurs within the city and its administrative borders (LISZEWSKI 1999). It is difficult to define it and, so far, no procedure for its identification has been elaborated on the basis of the guidebook analysis method.

The guidebook analysis method may also be used for more advanced statistical comparative analyses (LISZEWSKI 2014, p. 42), which is why the tourism space of the Maghreb cities, chosen for the research, was compared. The was created by grouping urban forms into functional types as defined by S. LISZEWSKI (1999). The index of relative similarity (the Renkonen similarity index), was used in tourism analyses to determine the degree of similarity (GONIA 2010). It determines the degree of compatibility of two aspects, i.e. in this case elements of tourism space from two cities - if possible - in the same year (after CHOMATOWSKI \& SO-KOŁOWSKI 1978). It was calculated based on the index ${ }^{2}$. Then the values of the Renkonen index were averaged for a given city in specific periods using the arithmetic mean. The comparative study covered the period from 1919 because this was the year when the first guide-book on Marrakesh was published (Table 1).

Table 1. Averaged Renkonen similarity index for the tourism space of selected cities of the Maghreb: 1919-2014

\begin{tabular}{|l|c|c|c|}
\hline \multirow{2}{*}{ City } & \multicolumn{3}{|c|}{ Period } \\
\cline { 2 - 4 } & $\begin{array}{c}\text { colonial } \\
(1919-1955)\end{array}$ & $\begin{array}{c}\text { postcolonial } \\
(1969-2014)\end{array}$ & $1919-2014$ \\
\hline Algiers & 0.89 & 0.67 & 0.78 \\
\hline Tunis & 0.88 & 0.72 & 0.78 \\
\hline Constantine & 0.88 & 0.66 & 0.77 \\
\hline Sousse & 0.84 & 0.61 & 0.68 \\
\hline Marrakesh & 0.90 & 0.72 & 0.79 \\
\hline Tangier & 0.66 & 0.68 & 0.67 \\
\hline
\end{tabular}
books.

Source: own research based on an analysis of tourist guide-

Throughout the researched period, Tangier's tourism space was the least similar to the other cities (the lowest value of the similarity index: 0.67 ). Especially in colonial times the similarity of this city in relation to the others was relatively low - at a level of 0.66 (in other cases, the value of the index oscillated between 0.84 and 0.90 ). Tangier had the status of an international zone where numerous civil liberties were guaranteed. It offered a lot of entertainment, for the needs of which the infrastructure was improved, benefiting both tourists and residents (elements of assimilation space). Other cities - Marrakesh, Algiers, Constantine, Tunis, Sousse - were part of the French colonial empire. Thus, the influence of the authorities on tourism space was similar there. The medinas of these cities were transformed into open-air museums of Islamic culture to answer the needs of tourists, mainly the French. Their tourism space was mainly made up of Arab-Berber monuments (elements of exploration and penetration spaces).

In the post-colonial period, the similarity of tourism space between the five cities (excluding Tangier) was less than the colonial period. The difference in the Renkonen similarity index values between these periods was 0.16-0.23. Urban tourism development strategies differed within a country. For example, one of Tunisia's main tourist resorts was established in Sousse, while cultural and business centres were set up in Tunis.

\section{Qualitative and spatial approach}

S. LISZEWSKI (2014) pointed out that spatial research on the evolution of urban tourism space can be carried out by:

a) drawing urban forms into a grid of primary fields - squares, hexagons or other geometrical figures - within their administrative borders. M. ŚWIESZCZAK (2007), in her studies on Heidelberg, assigned a certain functional type of tourism space to squares. If at least two types overlap within one field, then M. Świeszczak recognized only one that occupied a larger area or contained more elements defining that type. In the research on the six cities of the Maghreb, this approach could not be used. It was not possible to determine the geographical coordinates of some urban features, especially in colonial times. On the basis of guidebooks and other sources, it was often impossible to specify their location.

b) marking urban forms on a base-map with morphological units. In the case of the Maghreb cities researched, it was possible to do this. However, a large number of these units were not taken into account, because it was often impossible to determine the exact address of the urban features analysed when extracted from the guides. It was therefore limited to two morphological units. They were the medina with its winding narrow streets, as well as the area lying outside the medina, with a street layout similar to that of Western Europe.

According to S. LISZEWSKI (2014), the qualitative aspect of guidebook analysis is based, among other things, on determining the rank of urban features in 
tourism space. He identified the volume of text as one possible manifestation of such rank. The volume devoted to a given urban feature in a guidebook can be expressed as a percentage share of the total volume of text devoted to a given city by using character count as a measuring tool. However, this is a labourintensive activity. The nature of the majority of guidebooks selected for analysis enabled the author of this article to identify more efficiently the most important forms creating the tourism space of the selected Maghreb cities. Guide Bleu guidebooks used a star system to mark features that are especially attractive to tourists. By implication, the more attractive the feature was, the more tourists who visited it. Most likely, these were fragments of tourism penetration space. It is worth noting that the analysed guides do not always mark the same features with an asterisk - or in another measure - which they devoted the largest number of characters to.

\section{CONCLUSION}

This article raises issues in the possibility of studying the evolution of urban tourism space in the absence of (or very limited) source materials. Such is the case with the Maghreb. Data on urban tourism in this region is incomplete and hardly comparable and its credibility is questionable.

This article presents the pros and cons of using the guidebook analysis method in research on urban tourism-space evolution in the Maghreb countries. It presents some of the conclusions from the results of research carried out for a doctoral thesis based on a sample of six cities: Algiers and Constantine (Algeria), Marrakesh and Tangier (Morocco), Tunis and Sousse (Tunisia).

The biggest advantage of the guidebook analysis method proposed by S. LISZEWSKI is the long-term tracking of changes taking place in the tourism space of the cities of Maghreb. Tourism guidebooks are actually the only type of source with comparable data on urban tourism for the area in question covering a period of over a hundred years. Analysis of their content guarantees the acquisition of standardized data, thanks to which urban tourism space can be analysed on many levels. The assignment of urban forms to one of the five functional types of tourism space (LISZEWSKI 1999) makes it possible to compare this space from one city to another (on the basis of - for example - the Renkonen similarity index). In addition, the way in which some of the guidebooks used in the study were developed - such as the graphic distinction of selected features in the Guide Bleu series by the Hachette publishing house - makes it possible to track changes in the attractiveness of tourism space. This is a simple method for conducting qualitative research, yet it has not been described in the literature before.

The limitations regarding the possibility of using the guidebook analysis method in research on the evolution of urban tourism space in the Maghreb are a result of the nature of the tourist guides available rather than the specificity of the area itself. Their composition and the biographical profile of their authors have a greater impact on the analysis than the cultural diversity of the region as such. The use of the guidebook analysis method is limited e.g. due to the ideological commitments of their creators from colonial times. In quantitative studies, the use of some statistical methods given the fairly small number of variables obtained from guidebook analysis, is questionable. In the case of more sophisticated spatial studies, the guidebook analysis method - even with the support of other methods of analysis - is ineffective as it is often impossible to determine the geographical coordinates of some of the urban forms creating the tourism space.

\section{ENDNOTES}

1 In some cities of the Maghreb, medinas are the historic centres which still function and still have inhabitants. It was assumed that a historical city of this region is a city which, within its administrative boundaries, consists of two parts, namely: a. the medina created in the Middle Ages during Arab rule, b. a new town which includes a European district created and developed in colonial times and other districts created during the post-colonial period.

2 The Renkonen index is the quotient of the sum of the smaller values of indices for a given pair of sets and the sum of the larger values of indices for the same pair of sets. The closer it is to 1, the more alike are the compared domains (GONIA 2010).

\section{BIBLIOGRAPHY}

BARTHES R., 1957, Mythologies, Points Seuil, Paris.

BERTHONNET A., 2006, Le tourisme en Algérie (de 1880 aux années 1940): une histoire à écrire, Revue Tourisme, 15, pp. 1-15.

BOUTBOUQALT T., 2009, Mobilités coloniales et propagande touristique au Maroc: fondements de base et processus d'évolution, [in:] H. Kazdaghli, C. Zytnicki (eds.), Le tourisme dans l'empire français: Politiques, pratiques et imaginaires (XIXeXXe siècles), Société Française d'Histoire d'Outre-Mer, Paris, pp. 97-109.

CHOMĄTOWSKI S., SOKOŁOWSKI A., 1978, Taksonomia struktur Przegląd Statystyczny, 2, pp. 217-222.

GONIA A., 2010, Znaczenie województwa kujawsko-pomorskiego w turystyce bydgoskich szkół, [in:] W. Żukow, R. Muszkieta, M. Napierała, M. Barczak (eds.), Stan i rozwój regionalnej turystyki, rekreacji i rehabilitacji, Wyższa Szkoła Gospodarki, Bydgoszcz, pp. 66-87. 
JORDI J.J., 2009, Le temps des hiverneurs: les Anglais en Algérie (1880-1914), [in:] H. Kazdaghli, C. Zytnicki (eds.), Le tourisme dans l'empire français: Politiques, pratiques et imaginaires (XIXeXXe siècles), Société Française d'Histoire d'Outre-Mer, Paris, pp. 29-36.

KALASKA M., WITES T., 2015, Perception of the relations between former colonial powers and developing countries, Third World Quarterly, 36, 10, pp. 1809-1826.

KAŁASKA M., 2015a, Changes in the distribution of quantitative features of guest houses in the Medina of Marrakesh, Miscellanea Geographica - Regional Studies on Development, 19, 1, pp. 5-11.

KAŁASKA M., 2015b, Teoretyczna i rzeczywista przestrzeń penetracji turystycznej na przykładzie Marrakeszu w czasach kolonialnych. Ujęcie metodologiczne, [in:] M. Durydiwka, K. Duda-Gromada (eds.), Przestrzeń w turystyce. Znaczenie i wykorzystanie, Uniwersytet Warszawski, Wydział Geografii i Studiów Regionalnych, Warszawa, pp. 485-514.

KAŁASKA M., 2017, Przestrzeń turystyczna w strukturze miasta na wybranych przyktadach z państw Maghrebu, doctoral dissertation in the Faculty of Geography and Regional Studies University of Warsaw, Warszawa.

KARASEK K., 2013, Przestrzeń turystyczna Bydgoszczy, master's thesis in the Institute of Urban Geography and Tourism Studies University of Łódź, Łódź.

KIREGYERA B., 2015, The emerging data revolution in Africa: Strengthening the statistics, policy and decision-making chain, Sun Press, Stellenbosch.

KOWALCZYK A., 2011, Geograficzne aspekty przestrzeni turystycznej (Nowe spojrzenia na koncepcje przestrzeni turystycznej), [in:] M. Durydiwka, K. Duda-Gromada (eds.), Przestrzeń turystyczna. Czynniki, różnorodność, zmiany, Uniwersytet Warszawski, Wydział Geografii i Studiów Regionalnych, Warszawa, pp. 29-38.

KOWALCZYK A., 2015, Przestrzeń turystyczna - wieloznaczność pojęcia, [in:] M. Durydiwka, K. Duda-Gromada (eds.), Przestrzeń turystyczna. Znaczenie $i$ wykorzystanie, Uniwersytet Warszawski, Wydział Geografii i Studiów Regionalnych, Warszawa, pp. 11-26.

KOWALCZYK A., DEREK M., 2010, Zagospodarowanie turystyczne, Wydawnictwo Naukowe PWN, Warszawa.

LEROUX S., 2008, Le rapport à l'autre à travers le rapport à l'espace: l'example du tourisme français à Marrakech, doctoral dissertation in Université des Sciences et Technologie Lille 1, Lille.
LI Y., XIAO L., YE Y., XU W., LAW A., 2016, Understanding tourist space at a historic site through space syntax analysis: The case of Gulangyu, China, Tourism Management, 52, pp. 30-43.

LISZEWSKI S., 1995, Przestrzeń turystyczna, Turyzm, 5, 2, pp. 87-103.

LISZEWSKI S., 1999, Przestrzeń turystyczna miasta (przykład Łodzi), Turyzm, 9, 1, pp. 51-73.

LISZEWSKI S., 2014, Urban tourism space research methods: Evolution and patterns, Turyzm, 24, 1, pp. 35-44.

MAJDOUB W., 2011, Médina de Sousse: les enjeux de la gestion touristique d'une ville historique inscrite au patrimoine mondial, Téoros, 30, pp. 47-58.

MROZIŃSKA J., 2006, Rozwój przestrzeni turystycznej Warszawy $w X X$ wieku w świetle treści przewodników, master's thesis in the Institute of Urban Geography and Tourism Studies University of Łódź, Łódź.

RICARD P., 1954, Maroc, Hachette, Paris.

SZCZEPANIAK A., 2004, Rozwój przestrzeni turystycznej Krakowa na podstawie analizy treści przewodników turystycznych, master's thesis in the Institute of Urban Geography and Tourism Studies University of Łódź, Łódź.

ŚWIESZCZAK M., 2007, Przestrzeń turystyczna Heidelbergu, master's thesis in the Institute of Urban Geography and Tourism Studies University of Łódź, Łódź.

TRABELSI M., 2011, La médina de Tunis: tourisme, patrimoine et gentrification, master's thesis in the Universite Paris 1, Paris.

WIDMER-MÜNCH R., 1990, Des Tourismus in Fes und Marrakech: Strukturen und Prozesse in bipolaren Urbanraumen des islamischen Orients, Wepf \& Co, Basel.

WiTES T., 2011, Przestrzeń turystyczna w Brunei, [in:] M. Durydiwka, K. Duda-Gromada (eds.), Przestrzeń turystyczna. Czynniki, różnorodność, zmiany, Uniwersytet Warszawski, Wydział Geografii i Studiów Regionalnych, Warszawa, pp. 413-422.

WITES T., 2015, Przestrzeń turystyczna w krajach rozwijających się. 20 lat od koncepcji Martina Oppermanna, [in:] Przestrzeń turystyczna. Znaczenie i woykorzystanie, M. Durydiwka, K. Duda-Gromada (eds.), Uniwersytet Warszawski, Wydział Geografii i Studiów Regionalnych, Warszawa, pp. 67-86.

WŁODARCZYK B., 2009, Przestrzeń turystyczna. Istota. Koncepcje. Determinanty rozwoju, Wyd. Uniwersytetu Łódzkiego, Łódź.

ŻEBROWSKA A., 1996, Obraz turystyczny Łodzi w świetle analizy zawartości treści przewodników, master's thesis in the Institute of Urban Geography and Tourism Studies University of Łódź, Łódź.
Article received:

15 August 2018 Accepted:

28 September 2018 